\title{
Ortaokul Beşinci Sınıf Öğrencilerinin Dijital Okuryazarlık Düzeylerinin İncelenmesi
}

Şenol Mail Pala ${ }^{1}$
Adem Başıbüyük ${ }^{2}$
Type/Tür:

Research/Araştırma

Received/Geliş Tarihi:

January 9/9 Ocak 2020

Accepted/Kabul Tarihi:

June 10/10 Haziran 2020

Page numbers/Sayfa No:

897-921

Corresponding

Author/Illetişimden

Sorumlu Yazar:

senolmailpala@gmail.com

\section{$\checkmark$ iThenticate}

This paper was checked for plagiarism using

iThenticate during the preview process and before publication. / Bu çalışma ön inceleme sürecinde ve yayımlanmadan önce iThenticate yazılımı ile taranmıştır.

Copyright (C) 2017 by Cumhuriyet University, Faculty of Education. All rights reserved.

\begin{abstract}
Öz
Bilişim ve iletişim teknolojilerinde yaşanan gelişmelerle birlikte dijital teknolojiler hayatımızın önemli bir unsuru hâline gelmiştir. Birçok alanda olduğu gibi eğitimde de dijital teknolojilerden faydalanılmaktadır. Ancak, bireylerin dijital teknolojilerden daha iyi faydalanabilmeleri için bazı becerileri kazanması gerekmektedir. Dijital okuryazarlık becerisi de bu becerilerin önde gelenlerinden birisidir. Bu nedenle, dijital okuryazarlık becerisine öğretim programlarında da yer verilmeye başlanmıştır. Bu programlardan birisi de Sosyal Bilgiler Dersi Öğretim Programı'dır (2018). Bu durumdan yola çıkarak çalışmada ortaokul beşinci sınıf öğrencilerinin dijital okuryazarlık becerilerini çeşitli değişkenler açısından incelemek amaçlanmıştır. Çalışmada, nicel araştırma yöntemlerinden biri olan ilişkisel tarama modeli kullanılmıştır. Çalışmanın örneklemi, 2017-2018 eğitim-öğretim yılının bahar döneminde, Erzincan ilinde tespit edilen on sekiz ortaokulda öğrenim gören toplam 742 beşinci sinif öğrencisinden oluşmaktadır. Veri toplama aracı olarak 'Kişisel Bilgi Formu (KBF)' ve 'Dijital Okuryazarlık Ölçeği (DOÖ)' kullanılmıştır. Çalışmanın sonuçlarına göre araştırmaya katılan öğrencilerin genel olarak dijital okuryazarlık becerisi puanlarının yüksek olduğu belirlenmiştir. Öğrencilerin dijital okuryazarlık becerisi düzeylerinin; yerleşim yeri, kardeş sayısı, anne ve baba eğitim durumu, anne ve baba mesleği, sosyal bilgiler dersi karne notu, evlerinde bilgisayar veya tablet olması durumu, evlerinde internet bağlantısı olması durumu ve internete bağlanma sıklığına göre anlamlı bir şekilde farklılaştığı görülmüştür. Ancak, öğrencilerin dijital okuryazarlık düzeylerinin cinsiyete göre anlamlı olarak farklılaşmadığı sonucuna ulaşılmıştır.
\end{abstract}

Anahtar Kelimeler: Sosyal bilgiler, dijital okuryazarlık, teknoloji.

\section{Suggested APA Citation/Önerilen APA Atıf Biçimi:}

Pala, Ş. M., \& Başıbüyük, A. (2020). Ortaokul beşinci sınıf öğrencilerinin dijital okuryazarlık düzeylerinin incelenmesi. Cumhuriyet International Journal of Education, 9(3), 897-921. http://dx.doi.org/10.30703/cije.672882

\footnotetext{
* Bu makale Şenol Mail PALA tarafından hazırlanan doktora tezinin bir bölümünden üretilmiştir.

${ }^{1}$ Dr. Öğretmen, Erzincan Bilim ve Sanat Merkezi, Erzincan/Türkiye

Dr. Teacher, Erzincan Science and Art Center, Erzincan/Turkey

e-mail: senolmailpala@gmail.com ORCID ID: orcid.org/0000-0002-0489-9557

2 Prof. Dr., Erzincan Binali Yıldırım Üniversitesi, Fen Edebiyat Fakültesi, Coğrafya Bölümü, Erzincan/Türkiye Prof. Dr., Erzincan Binali Yıldırım University, Faculty of Arts and Sciences, Department of Geography, Erzincan/Turkey e-mail: abbuyuk@gmail.com ORCID ID: orcid.org/0000-0001-8597-6915
} 


\title{
The Investigation of Digital Literacy of Fifth Grade Secondary School Students
}

\begin{abstract}
With the developments in information and communication Technologies, digital Technologies nearly became an indispensable part of our life. As in many fields, education benefits from digital technology as well. However, it is required for individuals to gain some skills to benefit from digital technologies much better. Digital literacy skill is one of the leading skills, too. That's why; digital literacy skill has been introduced and involved in programs of instruction. One of these programs is 2018 Social Studies Curriculum. Based on this situation it is aimed at examining the digital literacy skills of 5 th grade secondary students in terms of various variables. Correlational Survey Model, which is quantitative method, was used in the study. The sample of the study consists of a total of 7425 th grade students who study at 18 different secondary schools specified in Erzincan Province at the spring semester of 2017-2018 academic year. As data collection tool, 'Personal Knowledge Form' and 'Digital Literacy Skill Scale' was used. It was determined that students attending the study have high level of digital literacy skill scores in general according to results of the study. It was concluded that students' digital literacy levels are different from one another significantly depending on; settlement, number of sibling, mother's and father's occupation, school report mark of Social Studies, whether there is computer or tablet at their homes, having internet connection at home and the frequency of connecting to the internet. However, it was cocncluded that students' digital literacy level did not change significantly according to gender.
\end{abstract}

Keywords: Social studies, digital literacy, technology.

\section{Giriş}

Ekonomik, kültürel, sosyal gelişmeler ve değişimler nedeniyle bireylerin çeşitli alanlarda kazanımlara ve bu kazanımları hayatlarına yansıtabilmeleri için çeşitli becerilere ihtiyaçları vardır. Bu ihtiyaçları karşılamak adına ülkemizde program geliştirme çalışmaları sürekli olarak yapılmaktadır (Gömleksiz ve Cüro, 2011). Bu doğrultuda 2018 'de güncellenen öğretim programlarında her derse ait becerileri bireylere temel düzeyde kazandırmak amaçlanmıştır (Milli Eğitim Bakanlığı [MEB], 2018). Beceri kazandırma öğretim programlarının amaçları içerisinde yer almaktadır. Sosyal bilgiler dersinin amac1; toplumsal problemlere duyarlı, bazı beceri ve değerleri kazanmış etkin vatandaş yetiştirmek olduğundan, beceri kazandırmak sosyal bilgiler dersi için de oldukça önemlidir (Avcı ve Faiz, 2018). Bu nedenle, 2018 Sosyal Bilgiler Dersi Öğretim Programı'nda (SBDÖP) öğrencilere kazandırılması hedeflenen bazı becerilere yer verilmiştir. Bu becerilerden bir tanesi de dijital okuryazarlık becerisidir.

Bilişim ve iletişim teknolojileri; eğitime birçok imkân sunmakla birlikte bir takım sorunları da beraberinde getirmektedir. Bu sorunları çözebilmenin en önemli yollarından birisi, dijital vatandaşlık ile ilgili bilgi, beceri ve tutumların bireylere kazandırılmasıdır (Ünal, 2017). 'Dijital vatandaşlık' kavramı, bilişim ve iletişim teknolojilerinde gelişmelerin hızla artmasıyla birlikte ortaya çıkmıştır (Öztürk, 2015). Dijital vatandaşlı̆̆ın dokuz unsuru bulunmaktadır. Bunlar: dijital erişim, dijital ticaret, dijital iletişim, dijital okuryazarlık, dijital etik, dijital hukuk, dijital haklar ve sorumluluklar, dijital sağlık, dijital güvenliktir (Ribble, 2011: 44).

Dijital vatandaşlığın unsurları içerisinde yer alan dijital okuryazarlık kavramını 1990'lı yılların sonunda ilk kez Gilster kullanmıştır (Meyers, Erickson ve Small, 2013). 
Gilster'e (1997) göre dijital okuryazarlık; “öğrenciler, araştırmacılar, yazarlar, yatırımcılar ve çalışmalarını desteklemek için online olarak mevcut olan bol kaynakları kullanmak isteyen herkes için önemli bir okumadır". Günümüzde 'dijital okuryazarlık' kavramının birçok tanımı yapılmaktadır. Ribble'ye (2011: 26) göre dijital okuryazarlık, "teknoloji kullanımı ve teknoloji hakkında öğrenme ve öğretme sürecidir". Martin'e (2005) göre dijital okuryazarlık; “dijital araç kullanabilmek için bireylerin farkındalık, tutum ve yeteneklerini geliştirmesi, dijital kaynaklara erişmesi, eriştiklerini değerlendirebilmesi, entegre, analiz ve sentez edebilmesi, yeni bilgi oluşturabilmesi, kişilerle iletişim kurabilmesi, yapıcı sosyal eylemlerle bu süreci sosyal hayatına yansıtabilmesidir". Özerbaş ve Kuralbayeva'ya (2018) göre dijital okuryazarlık; "efektif ve ciddi bir şekilde internet üzerinden araştırma yapmak, değerlendirmek ve çeşitli dijital teknolojilerden yararlanarak bilgi toplamaktır". Bu tanımlardan doğrultusunda dijital okuryazarlık becerisi; dijital teknolojileri kullanarak bilgiye ulaşabilme, işlem yapabilme, problem çözebilme, bu teknolojileri güvenli ve etkili bir şekilde kullanabilme yeteneği olarak ifade edilebilir.

Dijital teknolojilerde yaşanan gelişmelerin okuma ve yazma becerilerini değiştirmesiyle birlikte dijital okuryazarlık becerisi her bireyin sahip olması gereken temel beceriler içerisinde yer almaya başlamıştır (Maden, Maden ve Banaz, 2018; Karabacak ve Sezgin, 2019). Teknolojiyi nasıl, neden kullanmamız ve ne kadar faydalanmamız gerektiğini bilmek önemli bir ihtiyaç olmuştur. Dijital okuryazarlık, dijital teknolojiler konusunda yol gösterici olduğu için günlük hayatımızı etkileyen önemli bir beceri haline gelmiştir (Özerbaş ve Kuralbayeva, 2018).

Dijital teknolojinin gelişmesiyle birlikte; dijital vatandaşlik, e-Devlet, sanal ticaret ve sosyal medya gibi durumlar ortaya çıkmıştır. Bu durumlar; dijital bölünmüşlük, kimlik hırsızlığı, kişisel bilginin gizliliği, siber dolandırıcılık ve siber zorbalık gibi bazı sorunların ortaya çıkmasına neden olmuştur (MEB, 2018). Bireyler, internetten edindiği bilgileri kullanırken veya sosyal medyada tanıştıkları kişiler ile iletişim kurarken dikkatli olmalıdır. Bireylerin; güvenli ve bilinçli internet kullanımı, edindikleri bilgilerin doğruluğunu kontrol edebilme ve karşılaştıkları sorunları çözme gibi dijital okuryazarlık becerilerini kazanmaları önemlidir. Aksi takdirde edinilen bilgiler; yanlış, güvenirliği düşük ve doğruluğu kontrol edilmemiş olabilir. $\mathrm{Bu}$ durum da bireyler ve toplum için olumsuz durumların yaşanmasına yol açabilir (Hamutoğlu, Güngören, Uyanık ve Erdoğan, 2017).

Günümüzde internetin yaygınlaşmasıyla birlikte öğrenciler, dijital dünyada daha fazla yer almaya başlamıştır (Bozkurt ve Çoşkun, 2018). Dolayısıyla, eğitim alanındaki dijitalleşmeyle birlikte dijital okuryazarlık becerisi, öğrencilerin kazanması gereken bir beceri haline gelmiştir (Stripling, 2010). Bu nedenle, dijital teknoloji ve eğitim konusundaki tartışmalar; bireylerin teknolojiyi etkili ve eleştirel bir şekilde kullanmak için ihtiyaç duydukları yeterlilik ve anlayış biçimlerine, dolayısıyla dijital okuryazarlık üzerine yoğunlaşmış (Buckingham, 2010) ve bu beceriyle ilgili çeşitli araştırmalar yapılmıştır.

Malkoç (2018), beşinci sınıf öğrencilerinin sosyal bilgiler dersinde bilgisayar ve internet teknolojilerini kullanmasının öğrencilerin akademik başarılarını ve sosyal bilgiler dersine ilişkin tutumlarını olumlu yönde etkilediğini belirtmiştir. Sisco (2008), teknoloji okuryazarlığı ile ortaokul öğrencilerinin akademik başarılarının ilişkili olduğuna ulaşmıştır. Özerbaş ve Kuralbayeva (2018), yaşanılan ülke, kişisel 
bir bilgisayar ve internet bağlantısına sahip olma, internet kullanma sıklığ1 ve cinsiyetin dijital okuryazarlık üzerinde etkili olduğunu belirtmişlerdir. Acar (2015), anne ve babalara göre ilkokul, ortaokul ve lise öğrencilerinin dijital okuryazarlık becerisinin sınıf düzeyi ile yaşlarına göre farklılaştığına ulaşmıştır. Öztürk (2015), ortaokul öğrencilerinin teknolojik iletişim araçlarını yaygın olarak kullandıklarını ancak bu konuda haklarını ve sorumluluklarını yeterince bilmediklerini tespit etmiştir. Martin ve Grudziecki (2006), dijital okuryazarlığın; eğitime katılım, istihdam ve sosyal hayatın diğer yönlerini etkileyen önemli bir faktör olduğuna ulaşmışlardır. Blıkstad-Balas (2015), öğretmenlerin sınıf ortamında görsel teknolojiler kullanmasının, ortaokul öğrencilerin bazı dijital okuryazarlık becerilerini geliştirdiğini belirtmiştir. Meyers, Erickson ve Small (2013), dijital okuryazar bireylerin teknolojik araçların kullanımıyla ilgili beceri ve yeteneklerinin yanı sıra teknolojik araçların uygun kullanımı hakkında bilgi sahibi olmaları gerektiğini belirtmiştir. Knobel ve Lankshear (2006), dijital okuryazarlığın giderek eğitimin resmi bir hedefi olarak tanımlandığını ifade etmişlerdir.

Dijital teknolojiler ve sosyal ağların etkin bir şekilde kullanılmasıyla birlikte dijital dünyayla ilgili beceri ve yeterliliklere öğretim programlarında yer verilmeye başlanmıştır (Gelen, 2017). Dijital vatandaşlık yeterliliklerini geliştirmek amacıyla öğretim programlarında konuyla ilgili ders içi ve ders dişı etkinlikler yer almıştır (MEB, 2018). Bu bakımdan hayatın içerisinde yer alan ve günün şartlarına uyum sağlayacak etkin vatandaşlar yetiştirmeyi hedefleyen SBDÖP'te dijital okuryazarlık becerisine yer verilmiştir.

Dijital okuryazarlık, 5. Sınıf SBDÖP'e 'Bilim, Teknoloji ve Toplum' öğrenme alanında öğrencilere kazandırılması hedeflenen bir beceri olarak dâhil edilmiştir. Ayrıca programda; yetkinlikler, amaçlar, dikkat edilecek hususlar ve kazanımlarda da bu beceriye vurgu yapılmıştır. Bu çalışmada ortaokul 5. sınıf öğrencilerinin dijital okuryazarlık becerilerini; yerleşim yeri, cinsiyet, kardeş sayısı, anne-baba eğitim düzeyi, anne-baba mesleği, sosyal bilgiler dersi karne notu, evlerinde bilgisayar veya tablet olması durumu, evlerinde internet bağlantısı olması durumu ve internete bağlanma sıklığı değişkenleri açısından incelemek amaçlanmıştır. Literatürde ortaokul öğrencileri ile dijital okuryazarlık becerisine yönelik yapılan çok fazla çalışmaya rastlanılmadığı için çalışma önemli görülmektedir. Ayrıca, çalışma sonuçlarının Türkçe literatürde dijital okuryazarlık kavramının güçlendirilmesine katkı sağlayacağı düşünülmektedir.

\section{Araştırma Modeli}

\section{Yöntem}

$\mathrm{Bu}$ çalışma, ilişkisel tarama modelinin kullanıldı̆̆ modelinde, evren içinden seçilen bir örneklemden elde edilen verilerle evren hakkında çıkarımlarda bulunulur ve örneklemden ulaşılan sonuçlar evrene genellenir. Bu model, örneklemden yola çıkarak evrenin genelindeki eğilim, tutum ve görüşlerin nicel ya da nümerik bir şekilde betimlenmesine imkân verir (Creswell, 2016: 155-157). Tarama modeli, geçmişte veya şu anda devam eden bir durumu olduğu şekliyle ortaya koymayı amaçlar. Araştırma konusu, mevcut koşullar çerçevesinde ve olduğu gibi açıklanmaya çalışılır (Karasar, 2017: 109). İlişkisel tarama modellerinde ise en az iki değişken arasındaki değişimin durumunu belirlemek amaçlanır. Bu tür tarama modelleri ilişkilerin yorumlanmasına ve kestirilmesine 
olanak sağlar. İlişkisel taramada, korelasyon ve karşılaştırma türü ile ilişki kurulabilir (Kıncal, 2017: 113-114). Bu çalışmada dijital okuryazarlık becerisiyle cinsiyet, kardeş sayısı, anne ve baba eğitim düzeyi, anne ve baba mesleği gibi çeşitli değişkenler arasındaki ilişki incelendiği için ilişkisel tarama yöntemi kullanılmıştır.

\section{Evren ve Örneklem}

Araştırmanın evreni, Erzincan ilinde yer alan ortaokul beşinci sınıf öğrencileridir. Çalışmanın örneklemini ise Erzincan ilinde belirlenmiş 18 farklı ortaokulda öğrenim gören 742 beşinci sınıf öğrencisi oluşturmaktadır. Örneklem belirlenirken kasti (kararsal) örnekleme tekniği kullanılmıştır. Bu tekniğe göre örneklem araştırmacı tarafından araştırma problemlerine cevap bulabileceği kişilerden seçilir. Örneklemin belirlenmesindeki ölçüt, araştırmacının örneklemin ihtiyacı karşılayacağı düşüncesidir (Altunışık, Coşkun, Bayraktaroğlu ve Yıldırım, 2005: 132). Ayrıca, çalışmanın gerçekleştirildiği 18 ortaokuldan 11'i il merkezinde (bir okul özel okul statüsündedir), 4'ü merkeze bağlı beldelerde ve 3'ü ise farklı ilçe merkezinde yer almaktadir.

Çalışmaya katılan öğrencilerin yerleşim yeri ve cinsiyetlerine ilişkin betimsel veriler Tablo 1'de gösterilmiştir.

Tablo 1

Çalışmaya Katılan Öğrencilerin Yerleşim Yeri ve Cinsiyetlerine İlişkin Betimsel Veriler

\begin{tabular}{llll}
\hline Değişken & & $\mathbf{N}$ & $\mathbf{0}$ \\
\hline \multirow{3}{*}{ Yerleşim Yeri } & Merkez & 577 & 77,7 \\
\cline { 2 - 4 } & Belde & 85 & 11,5 \\
\cline { 2 - 4 } & $\dot{\text { İçe }}$ & 80 & 10,8 \\
\cline { 2 - 4 } & Toplam & $\mathbf{7 4 2}$ & $\mathbf{1 0 0}$ \\
\hline \multirow{3}{*}{ Cinsiyet } & Erkek & 365 & 49,2 \\
\cline { 2 - 4 } & Kiz & 377 & 50,8 \\
\cline { 2 - 4 } & Toplam & $\mathbf{7 4 2}$ & $\mathbf{1 0 0}$ \\
\hline
\end{tabular}

Tablo 1'de öğrencilerin \%77,7'sinin (577) il merkezinde, \%11,5'inin (85) il merkezine bağlı beldelerde ve \%10,8'inin (80) ilçe merkezlerinde ikamet ettiği görülmektedir. Çalışmada il merkezinde ikamet eden öğrencilerin oranı diğerlerinden daha yüksektir. Bu durumun sebebi; il merkezinde yer alan öğrencilerin sayısının, belde ve ilçe merkezine yer alan öğrenci sayısından oldukça fazla olmasıdır. Öğrencilerin \%49,2'si (365) erkek, \%50,8'i ise k1z olduğu, katılımcıların cinsiyete göre oranlarının birbirine yakın olduğu görülmektedir.

\section{Veri Toplama Araçları}

Çalışmada veri toplama aracı olarak 'Kişisel Bilgi Formu' ve 'Dijital Okuryazarlık Ölçeği' kullanılmıştır.

Kişisel bilgi formu (KBF). Araştırmaya katılan öğrenciler hakkında çeşitli bilgiler edinmek amacıyla on maddeden oluşan kişisel bilgi formu hazırlanmıştır. Bu formda öğrencilerin; cinsiyeti, yerleşim yeri, kardeş sayısı, anne ve baba eğitim düzeyleri, anne ve baba mesleği, evlerinde bilgisayar/tablet ve internet bağlantısı olma durumu ve internete bağlanma sıklığı durumuna ilişkin betimlemeye yönelik olgusal sorulara yer verilmiştir. Ayrıca, öğrencilerin 2017-2018 eğitim ve öğretim yılı 
birinci dönem sosyal bilgiler dersi karne notları okul idarelerinden alınarak bu bölüme eklenmiştir.

Dijital okuryazarlık ölçeği (DOÖ). Ölçek, çalışmanın ilk yazarının doktora tezinde geliştirilmiştir (Pala, 2019). Ölçeğin yapı geçerliliği için önce Açımlayıcı Faktör Analizi (AFA) sonra da Doğrulayıcı Faktör Analizi (DFA) yapılmıştır.

Çalışmada AFA için temel bileşenler analizi yöntemi kullanılmıştır. AFA'da ölçek maddelerinin faktör yük değerlerine bakılmıştır. Faktör yük değerinin $\geq .45$ olması madde seçimi için iyi bir ölçütken, uygulamada az sayıda madde için bu sınır değer, .30'a indirilebilir (Büyüköztürk, 2008: 124). Ölçekteki en yüksek faktör yükünün .73 ve en düşük faktör yükünün .43 olduğu görülmüsstür. Dolayısıyla, DOÖ'nün faktör yükleri bakımından oldukça iyi bir ölçek olduğu görülmüştür (Büyüköztürk, 2008: 124).

Ölçeğe AFA'dan sonra DFA da uygulanıp maddeler arası ilişki (model) test edilmiştir. DFA, daha önceden belirlenmiş bir yapının, bir model olarak doğrulanıp doğrulanmadığının test edilmesidir (Çokluk vd., 2012: 275). Bu bağlamda çalışmada kullanılan DOÖ'nin yapı geçerliliği için DFA yapılmıştır. DOÖ'ye ait DFA uyum indeksleri Tabloda 2'de gösterilmiştir.

Tablo 2

Ölçme Modeli Uyum İndeksleri

\begin{tabular}{ccccc}
\hline $\begin{array}{c}\text { Uyum } \\
\text { İndeksi }\end{array}$ & $\begin{array}{c}\text { Mükemmel } \\
\text { Uyum }\end{array}$ & İyi Uyum & $\begin{array}{c}\text { Birinci Düzey } \\
\text { DFA'dan Elde Edilen } \\
\text { Uyum İndeksleri }\end{array}$ & $\begin{array}{c}\text { Birinci Düzey } \\
\text { DFA'dan Elde } \\
\text { edilen Uyum }\end{array}$ \\
\hline $\mathrm{X}^{2} / \mathrm{sd}$ & $0 \leq \mathrm{X}^{2} / \mathrm{sd} \leq 3$ & $3 \leq \mathrm{X}^{2} / \mathrm{sd} \leq 5$ & $\mathbf{2 , 7 2}$ & Mükemmel uyum \\
\hline RMSEA & $0 \leq \mathrm{RMSEA} \leq 0.05$ & $0.05 \leq \mathrm{RMSEA} \leq 0.08$ & $\mathbf{0 , 0 4}$ & Mükemmel uyum \\
\hline GFI & $0.95 \leq \mathrm{GFI} \leq 1.00$ & $0.90 \leq \mathrm{GFI} \leq 0.95$ & $\mathbf{0 , 9 4}$ & İyi uyum \\
\hline AGFI & $0.95 \leq \mathrm{AGFI} \leq 1.00$ & $0.90 \leq \mathrm{AGFI} \leq 0.95$ & $\mathbf{0 . 9 2}$ & İyi uyum \\
\hline RMR & $0 \leq \mathrm{RMR} \leq 0.05$ & $0.05 \leq \mathrm{RMR} \leq 0.08$ & $\mathbf{0 . 0 5}$ & Mükemmel uyum \\
\hline SRMR & $0 . \leq \mathrm{SRMR} \leq 0.05$ & $0.05 \leq \mathrm{SRMR} \leq 0.08$ & $\mathbf{0 . 0 4}$ & Mükemmel uyum \\
\hline CFI & $0.95 \leq \mathrm{CFI} \leq 1.00$ & $0.90 \leq \mathrm{CFI} \leq 0.95$ & $\mathbf{0 . 9 7}$ & Mükemmel uyum \\
\hline NFI & $0.95 \leq \mathrm{NFI} \leq 1.00$ & $0.90 \leq \mathrm{NFI} \leq 0.95$ & $\mathbf{0 . 9 6}$ & Mükemmel uyum \\
\hline NNFI & $0.95 \leq \mathrm{NNFI} \leq 1.00$ & $0.90 \leq \mathrm{NNFI} \leq 0.95$ & $\mathbf{0 . 9 7}$ & Mükemmel uyum \\
\hline
\end{tabular}

Tablo 2'de görüldüğü üzere uyum indekslerine ilişkin mükemmel ve kabul edilebilir uyum değerleri, DFA'dan elde edilen dört faktörlü modelin uyumlu olduğunu ve ölçeğin doğrulandığını göstermektedir.

Bir ölçeğin güvenilirliğinde kullanılan en yaygın objektif ölçüt Cronbach's Alpha analizidir (Tavakol ve Dennick, 2011: 53-55). Uygulama sonucu elde edilen verilerden yararlanarak Cronbach's Alpha güvenirlik analizi yapılmıştır. Ölçeğe ait Cronbach's Alpha katsayısı .877 olarak tespit edilmiştir. Ölçeğin Cronbach's Alpha güvenirlik katsayısı .70'in üzerinde çıktığı için ölçeğin güvenirlik açısından yeterli düzeyde olduğu görülmüştür (Büyüköztürk, 2008: 170-171).

\section{Verilerin Analizi}

Veriler toplandiktan sonra uygun bir şekilde doldurulan veri toplama araçları değerlendirmeye alınmıştır. Toplanan veriler, dijital ortama aktarılarak veri giriş tablosu oluşturulmuştur. Çalışmada belirlenen değişkenler çerçevesinde öğrencilerin 
dijital okuryazarlık becerilerine ilişkin betimleyici istatistikler ortaya konulmuştur. Çalışmada ikili karşılaştırmalar için bağımsız örnek t-testi, ikiden fazla gruba ait ortalamaları karşılaştırmak için tek yönlü ANOVA testi kullanılmıştır. Anlamlı fark bulunan durumlarda farkın kaynağını belirlemek için TUKEY testi sonuçlarından yararlanılmıştır.

\section{Bulgular}

Bu bölümde beşinci sınıf öğrencilerin; yerleşim yeri, cinsiyet, kardeş sayısı, anne ve baba eğitim durumu, anne ve baba mesleği, sosyal bilgiler dersi karne notu, evlerinde bilgisayar veya tablet olma durumu, evlerinde internet bağlantısı olma durumu ve internete bağlanma sıklığına göre dijital okuryazarlık becerilerine ilişkin bulgulara yer verilmiştir.

\section{Yerleşim Yerine Göre Öğrencilerin Dijital Okuryazarlık Becerilerine İlişkin Bulgular}

Yerleşim yerine göre öğrencilerin dijital okuryazarlık becerisi puanlarına ilişkin aritmetik ortalama ve standart sapmalar Tablo 3'te gösterilmiştir.

Tablo 3

Öğrencilerin Yerleşim Yerine Göre Dijital Okuryazarlık Becerisine İlişkin Betimleyici İstatistikler

\begin{tabular}{lccc}
\hline Yerleşim yeri & N & $\overline{\boldsymbol{X}}$ & Ss \\
\hline Merkez (M) & 577 & 79,97 & 12,88 \\
Belde (B) & 85 & 75,92 & 12,78 \\
İlce (I) & 80 & 73,21 & 11,71 \\
Toplam & $\mathbf{7 4 2}$ & $\mathbf{7 8 , 7 8}$ & $\mathbf{1 2 , 9 4}$ \\
\hline
\end{tabular}

Tablo 3'te il merkezinde yaşayan öğrencilerin dijital okuryazarlık becerisi puanlarının ortalamaları $(\bar{X}=79,97)$, merkez belde $(\bar{X}=75,92)$ ve ilçe merkezinde ( $\bar{X}=73,27)$ yaşayan öğrencilerin dijital okuryazarlık becerisi puanlarının ortalamalarından daha yüksek olduğu görülmektedir. Bütün öğrencilerin dijital okuryazarlık becerisi puanlarının ortalaması ise 78,78' dır.

Tablo 4

Öğrencilerin Yerleşim Yerine Göre Dijital Okuryazarlık Becerisine İlişkin Tek Yönlü ANOVA Testi Sonuçları

\begin{tabular}{lcccccc}
\hline Kareler & \multicolumn{5}{c}{ Kareler } \\
Varyansın Kaynağı & Toplamı & Sd & Ortalaması & F & p & Tukey \\
\hline Gruplar arası & 3993,057 & 2 & 1996,528 & 12,267 &, $000^{*}$ & M $>$ B, I \\
Grup içi & 120273,574 & 739 & 162,752 & & & \\
Toplam & 124266,631 & 741 & & & & \\
\hline${ }^{*} \mathrm{p}<.01$ & & & & &
\end{tabular}

Öğrencilerin yerleşim yerine göre dijital okuryazarlık becerisine ilişkin tek yönlü ANOVA testi sonuçları Tablo 4'te gösterilmiştir. Öğrencilerin yaşadıkları 
yerleşim yerine göre dijital okuryazarlık becerisi puanları arasında anlamlı bir fark olduğu Tablo 4'te görülmektedir $\left(\mathrm{F}_{(2-739)}=12,267, \mathrm{p}<.01\right)$. Öğrencilerin ikamet ettikleri yerlerin, öğrencilerin dijital okuryazarlık becerisi üzerinde etkili olduğu belirlenmiştir.

\section{2. Öğrencilerin Cinsiyete Göre Dijital Okuryazarlık Becerilerine İlişkin Bulgular}

Öğrencilerin cinsiyete göre dijital okuryazarlık becerisine ilişkin bağımsız örnek ttesti sonuçları Tablo 5'te gösterilmiştir.

Tablo 5

Öğrencilerin Cinsiyete Göre Dijital Okuryazarlık Becerisine İlişkin Bağımsız Örneklem T-Testi Sonuçlan

\begin{tabular}{lcccccc}
\hline Cinsiyet & N & $\overline{\boldsymbol{X}}$ & Ss & Sd & t & p \\
\hline Erkek & 365 & 78,78 & 13,86 & 740 &, 004 &, $997^{\star}$ \\
\hline Kadin & 377 & 78,77 & 12,01 & & & \\
\hline${ }^{*} \mathrm{p}>.05$ & & & & & &
\end{tabular}

Tablo 5'teki test sonuçlarına göre erkek ve kız öğrencilerin dijital okuryazarlık puanlarının birbirine yakın olduğu ve dijital okuryazarlık puanlarının cinsiyete göre anlamlı olarak değişmediği tespit edilmiştir $\left(\mathrm{t}_{(740)}=, 004, \mathrm{p}>.05\right)$.

\section{3. Öğrencilerin Kardeş Sayısına Göre Dijital Okuryazarlık Becerilerine İlişkin Bulgular}

Öğrencilerin kardeş sayısına göre dijital okuryazarlık becerisi puanlarına ilişkin aritmetik ortalama ve standart sapmalar Tablo 6 'da gösterilmiştir.

Tablo 6

Öğrencilerin Kardeş Sayısına Göre Dijital Okuryazarlık Becerisine İlişkin Betimleyici İstatistikler

\begin{tabular}{lccc}
\hline Kardeş sayıs1 & $\mathbf{N}$ & $\overline{\boldsymbol{X}}$ & Ss \\
\hline $0,00(1)$ & 68 & 81,10 & 11,56 \\
$1,00(2)$ & 252 & 80,70 & 13,39 \\
$2,00(3)$ & 212 & 78,40 & 12,12 \\
$3,00(4)$ & 117 & 75,82 & 12,23 \\
$4,00+(5)$ & 93 & 76,46 & 14,39 \\
Toplam & $\mathbf{7 4 2}$ & $\mathbf{7 8 , 7 8}$ & $\mathbf{1 2 , 9 4}$ \\
\hline
\end{tabular}

Dijital okuryazarlık becerisi puanlarının ortalamaları; kardeşi olmayan öğrencilerin 81,10, kardeş sayısi; bir olan öğrencilerin 80,70, iki olan öğrencilerin 78,40 , üç olan öğrencilerin 75,82 ve dört veya daha fazla olan öğrencilerin 76,46 olarak bulunmuştur. Tablo 6'ya göre en yüksek dijital okuryazarlık becerisi puanlarının kardeşi olmayan öğrencilere ait olduğu görülmüştür. 
Tablo 7

Öğrencilerin Kardeş Sayısına Göre Dijital Okuryazarlık Becerisine İlişkin Tek Yönlü ANOVA Testi Sonuçları

\begin{tabular}{lcccccc}
\hline & Kareler & Kareler & p & Tukey \\
Varyansın Kaynağ1 & Toplami & Sd & Ortalaması & F & p & $2>4,5$ \\
\hline Gruplar arası & 2856,813 & 4 & 714,203 & 4,335 &, $002^{*}$ & \\
Grup içi & 121409,818 & 737 & 164,735 & & & \\
Toplam & 124266,631 & 741 & & & \\
\hline
\end{tabular}

${ }^{*} \mathrm{p}<.01$

Kardeş sayısına göre öğrencilerin dijital okuryazarlık becerisi düzeyinin karşılaştırılmasına ilişkin tek yönlü ANOVA testi sonuçları Tablo 7'de gösterilmiştir. Tukey testi, 2 ile 4/5 grupları arasındaki farkın anlamlı olduğunu göstermektedir $\left(\mathrm{F}_{(4-737)}=4,335, \mathrm{p}<.01\right)$. Kardeş sayısının dijital okuryazarlık becerisi puanlarının üzerinde önemli bir değişken olduğu görülmüştür.

\section{Anne Eğitim Durumuna Göre Öğrencilerin Dijital Okuryazarlık Becerilerine İlişkin Bulgular}

Öğrencilerin anne eğitim durumuna göre dijital okuryazarlık becerisi puanlarına ilişkin aritmetik ortalama ve standart sapmalar Tablo $8^{\prime}$ de gösterilmiştir.

Tablo 8

Anne Ĕ̆itim Durumuna Göre Öğrencilerin Dijital Okuryazarlık Becerisine İlişkin Betimleyici İstatistikler

\begin{tabular}{lccc}
\hline Anne eğitim durumu & $\mathbf{N}$ & $\overline{\boldsymbol{X}}$ & Ss \\
\hline İlkokul (1) & 151 & 75,61 & 13,11 \\
Ortaokul (2) & 232 & 75,70 & 12,79 \\
Lise (3) & 226 & 79,23 & 12,10 \\
Üniversite (4) & 133 & 86,97 & 10,67 \\
Toplam & $\mathbf{7 4 2}$ & $\mathbf{7 8 , 7 8}$ & $\mathbf{1 2 , 9 4}$ \\
\hline
\end{tabular}

Dijital okuryazarlık becerisi puanlarının ortalamaları, annesinin mezuniyeti; ilkokul olan öğrencilerin 75,61, ortaokul olanların 75,70, lise olanların 79,23 ve üniversite olanların 86,97 olduğu görülmüştür.

Tablo 9

Anne Ĕ̆itim Durumuna Göre Öğrencilerin Dijital Okuryazarlık Becerisine İlişkin Tek Yönlü ANOVA Testi Sonuçları

\begin{tabular}{|c|c|c|c|c|c|c|}
\hline Varyansın Kaynağı & $\begin{array}{c}\text { Kareler } \\
\text { Toplamı } \\
\end{array}$ & Sd & $\begin{array}{c}\text { Kareler } \\
\text { Ortalaması } \\
\end{array}$ & $\mathbf{F}$ & p & Tukey \\
\hline Gruplar arası & 12685,872 & 3 & 4228,624 & 27,968 &, $000^{*}$ & $4>1,2,3$ \\
\hline Grup içi & 111580,759 & 738 & 151,193 & & & $3>1,2$ \\
\hline Toplam & 124266,631 & 741 & & & & \\
\hline
\end{tabular}


Anne eğitim durumuna göre öğrencilerin dijital okuryazarlık becerisi düzeyinin karşılaştırılmasına ilişkin tek yönlü ANOVA testi sonuçları Tablo 9`da gösterilmiştir. Test sonuçları gruplar arasındaki farkın anlamlı olduğunu göstermektedir $\left(\mathrm{F}_{(3-738)}=\right.$ $27,968, \mathrm{p}<.01$ ). Tukey testi, $4-1 / 2 / 3$ ve 3-1/2 grupları arasındaki farkın anlaml olduğunu göstermiştir. Dolayısıyla anne eğitim durumunun öğrencilerin dijital okuryazarlık becerisi puanlarının üzerinde etkili olduğu görülmektedir.

\section{Baba Eğitim Durumuna Göre Öğrencilerin Dijital Okuryazarlık Becerilerine} İlişkin Bulgular

Öğrencilerin baba eğitim durumuna göre dijital okuryazarlık becerisi puanlarına ilişkin betimleyici istatistikler Tablo 10' da gösterilmiştir.

Tablo 10

Baba Ĕ̆itim Durumuna Göre Öğrencilerin Dijital Okuryazarlkk Becerisine İlişkin Betimleyici İstatistikler

\begin{tabular}{lccc}
\hline Baba eğitim durumu & $\mathbf{N}$ & $\overline{\mathbf{X}}$ & Ss \\
\hline İlkokul (1) & 47 & 73,74 & 13,22 \\
Ortaokul (2) & 166 & 73,94 & 12,17 \\
Lise (3) & 284 & 76,77 & 12,77 \\
Üniversite (4) & 245 & 85,34 & 10,86 \\
Toplam & $\mathbf{7 4 2}$ & $\mathbf{7 8 , 7 8}$ & $\mathbf{1 2 , 9 4}$ \\
\hline
\end{tabular}

Dijital okuryazarlık becerisi puanlarının ortalamaları, babası; ilkokul mezunu olan öğrencilerin 73,74, ortaokul mezunu olan öğrencilerin 73,94, lise mezunu olan öğrencilerin 76,77 ve üniversite mezunu olan öğrencilerin 85,94 olduğu görülmüştür. En yüksek dijital okuryazarlık becerisi puanlarına sahip öğrencilerin baba eğitim durumunun üniversite olduğu tespit edilmiştir.

Tablo 11

Baba Eğitim Durumuna Göre Öğrencilerin Dijital Okuryazarlık Becerisine İlişkin Tek Yönlü ANOVA Testi Sonuçları

\begin{tabular}{lcccccc}
\hline & Kareler & \multicolumn{5}{c}{ Kareler } \\
Varyansın Kaynağı & Toplamı & Sd & Ortalaması & F & p & Tukey \\
\hline Gruplar aras1 & 16774,648 & 3 & 5591,549 & 38,389 &, $000^{*}$ & $4>1,2,3$ \\
Grup içi & 107491,983 & 738 & 145,653 & & & \\
Toplam & 124266,631 & 741 & & & & \\
\hline${ }^{*} \mathrm{p}<.01$ & & & & & &
\end{tabular}

Tablo 11'deki test sonuçları gruplar arasındaki farkın anlamlı olduğunu göstermektedir $\left(\mathrm{F}_{(3-738)}=38,389, \mathrm{p}<\right.$. 01). Tukey testi, $4-1 / 2 / 3$ grupları arasındaki farkın anlamlı olduğunu göstermiştir. Baba eğitim durumunun öğrencilerin dijital okuryazarlık becerisi puanlarının üzerinde etkili olduğu görülmektedir. 


\section{6. Öğrencilerin Anne Mesleğine Göre Dijital Okuryazarlık Becerilerine İlişkin Bulgular}

Anne mesleğine göre öğrencilerin dijital okuryazarlık becerisi puanlarına yönelik betimleyici istatistikler Tablo 12' de gösterilmiştir.

Tablo 12

Anne Mesleğine Göre Öğrencilerin Dijital Okuryazarlık Becerisine İlişkin Betimleyici İstatistikler

\begin{tabular}{lccc}
\hline Anne mesleği & N & $\overline{\boldsymbol{X}}$ & Ss \\
\hline Ev hanımı (1) & 564 & 77,47 & 12,68 \\
İşçi (2) & 43 & 76,74 & 14,52 \\
Memur (3) & 83 & 87,86 & 9,85 \\
Diğer (4) & 52 & 80,15 & 13,11 \\
Toplam & $\mathbf{7 4 2}$ & $\mathbf{7 8 , 7 8}$ & $\mathbf{1 2 , 9 4}$ \\
\hline
\end{tabular}

Dijital okuryazarlık becerisi puanlarının ortalamaları, annesi; ev hanımı olan öğrencilerin 77,47, işçi olanların 76,74, memur olanların 87,86 ve annesi diğer mesleklerde çalışan öğrencilerin 80,15 olduğu görülmüştür. Tablo 12'ye göre annesi memur olan öğrencilerin, en yüksek dijital okuryazarlık becerisi puan ortalamalarına sahip olduğu görülmektedir.

Tablo 13

Anne Mesleğine Göre Öğrencilerin Dijital Okuryazarlık Becerisine İlişkin Tek Yönlü ANOVA Testi Sonuçlarn

\begin{tabular}{lcccccc}
\hline $\begin{array}{l}\text { Varyansın } \\
\text { Kaynağı }\end{array}$ & $\begin{array}{c}\text { Kareler } \\
\text { Toplamı }\end{array}$ & Sd & $\begin{array}{c}\text { Kareler } \\
\text { Ortalaması }\end{array}$ & $\mathbf{F}$ & $\mathbf{p}$ & Tukey \\
\hline Gruplar arası & 8093,532 & 3 & 2697,844 & 17,138 &, $000^{*}$ & $3>1,2,4$ \\
Grup içi & 116173,099 & 738 & 157,416 & & & \\
Toplam & 124266,631 & 741 & & & & \\
\hline${ }^{*} \mathrm{p}<.01$ & & & & &
\end{tabular}

Tablo 13'teki sonuçlar gruplar arasındaki farkın anlamlı olduğunu göstermektedir $\left(\mathrm{F}_{(3-738)}=17,138, \mathrm{p}<.01\right)$. Farkın kaynağını tespit etmek için yapılan Tukey testi 3 ile 1/2/4 grupları arasındaki farkın anlamlı olduğunu göstermiştir. Anne mesleğinin, öğrencilerin dijital okuryazarlık becerisi puanlarının üzerinde etkili olduğu tespit edilmiştir.

\section{Baba Mesleğine Göre Öğrencilerin Dijital Okuryazarlık Becerilerine İlişkin Bulgular}

Tablo 14

Baba Mesleğine Göre Öğrencilerin Dijital Okuryazarlı Becerisine İlişkin Betimleyici İstatistikler

\begin{tabular}{lccc}
\hline Baba mesleği & N & $\overline{\boldsymbol{X}}$ & Ss \\
\hline İşçi (1) & 201 & 74,88 & 12,71 \\
Memur (2) & 204 & 83,25 & 11,94 \\
Diğer (3) & 337 & 78,40 & 12,88 \\
\hline Toplam & $\mathbf{7 4 2}$ & $\mathbf{7 8 , 7 8}$ & $\mathbf{1 2 , 9 4}$ \\
\hline
\end{tabular}


Tablo 14'te dijital okuryazarlık becerisi puanlarının ortalamaları; babası işçi olan öğrencilerin 74,88, babası memur olan öğrencilerin 83,25 ve babası diğer mesleklerde çalışan öğrencilerin 78,40 olduğu görülmüştür. Babası memur olan öğrencilerin, en yüksek dijital okuryazarlık becerisi puan ortalamasına sahip olduğu belirlenmiştir.

Tablo 15

Baba Mesleğine Göre Öğrencilerin Dijital Okuryazarlık Becerisine İlişkin Tek Yönlü ANOVA Testi Sonuçlar

\begin{tabular}{lcccccc}
\hline & Kareler & \multicolumn{5}{c}{ Kareler } \\
Ortalama & F & p & Tukey \\
Varyansın Kaynağı & Toplamı & Sd & S1 & F & \\
\hline Gruplar arası & 7173,093 & 2 & 3586,546 & 22,635 &, $000^{*}$ & $2>1,3 ;$ \\
Grup içi & 117093,538 & 739 & 158,449 & & & $3>1$ \\
Toplam & 124266,631 & 741 & & & & \\
\hline " $\mathrm{p}<.01$ & & & & &
\end{tabular}

Tablo 15'e göre gruplar arasındaki farkın anlamlı olduğu görülmektedir $\left(\mathrm{F}_{(2-739)}\right.$ $=22,635, \mathrm{p}<.01)$. Tukey testine göre $2-1 / 3$ ve 3-1 grupları arasındaki farkın anlaml olduğu tespit edilmiştir. Baba mesleğinin, öğrencilerin dijital okuryazarlık becerisi puanlarının üzerinde etkili olduğu görülmektedir.

\section{Sosyal Bilgiler Dersi Karne Notuna Göre Öğrencilerin Dijital Okuryazarlık Becerilerine İlişkin Bulgular}

Sosyal bilgiler dersi karne notuna göre öğrencilerin dijital okuryazarlık becerisi puanlarına ilişkin aritmetik ortalama ve standart sapmalar Tablo 16' da gösterilmiştir.

Tablo 16

Sosyal Bilgiler Dersi Karne Notuna Göre Öğrencilerin Dijital Okuryazarlık Becerisine İlişkin Betimleyici İstatistikler

\begin{tabular}{lccc}
\hline $\begin{array}{l}\text { Sosyal bilgiler dersi } \\
\text { karne notu }\end{array}$ & $\mathbf{N}$ & $\overline{\boldsymbol{X}}$ & Ss \\
\hline $1,000-2,00(2)$ & 35 & 55,17 & 9,98 \\
$3,00(3)$ & 85 & 67,29 & 9,56 \\
$4,00(4)$ & 164 & 72,99 & 10,30 \\
$5,00(5)$ & 458 & 84,79 & 9,71 \\
Toplam & $\mathbf{7 4 2}$ & $\mathbf{7 8 , 7 8}$ & $\mathbf{1 2 , 9 4}$ \\
\hline
\end{tabular}

Tablo 16' dan dijital okuryazarlık becerisi puanlarının ortalamaları; karne notu bir ve iki olan öğrencilerin 55,17, üç olanları 67,29, dört olanların 72,99 ve beş olanların 84,79 olduğu görülmektedir. Öğrencilerin, sosyal bilgiler dersi karne notu arttıkça, dijital okuryazarlık becerisi puanlarının da artmış olduğu görülmektedir. 
Tablo 17

Sosyal Bilgiler Dersi Karne Notuna Göre Öğrencilerin Dijital Okuryazarlık Becerisine İlişkin Tek Yönlü ANOVA Testi Sonuçları

\begin{tabular}{lcccccc}
\hline & Kareler & \multicolumn{3}{c}{ Kareler } \\
Varyansın Kaynağ1 & Toplamı & Sd & Ortalaması & F & p & Tukey \\
\hline Gruplar arası & 52757,141 & 3 & 17585,714 & 181,490 &, $000^{*}$ & $2<3,4,5 ;$ \\
Grup içi & 71509,490 & 738 & 96,896 & & & $3<4,5 ;$ \\
Toplam & 124266,631 & 741 & & & & $4<5$ \\
\hline${ }^{*} \mathrm{p}<.01$ & & & & &
\end{tabular}

Sosyal bilgiler dersi karne notuna göre öğrencilerin dijital okuryazarlık becerisi düzeyinin karşılaştırılmasına ilişkin tek yönlü ANOVA testi sonuçları Tablo 17'de gösterilmiştir. Öğrenci dijital okuryazarlık becerisi düzeylerinin, sosyal bilgiler dersi karne notuna göre anlamlı olarak değiştiği görülmektedir $\left(\mathrm{F}_{(3-738)}=181,490, \mathrm{p}<.01\right)$. Tukey testi $2-3 / 4 / 5,3-4 / 5$ ve 4-5 grupları arasındaki farkın anlamlı olduğunu göstermiştir. Test sonuçlarına göre, sosyal bilgiler dersi karne notunun, öğrencilerin dijital okuryazarlık becerisi üzerinde önemli bir etken olduğu belirlenmiştir.

\section{Evlerinde Bilgisayar veya Tablet Olması Durumuna Göre Öğrencilerin Dijital Okuryazarlık Becerilerine İlişkin Bulgular}

Tablo 18

Evlerinde Bilgisayar veya Tablet Olması Durumuna Göre Öğrencilerin Dijital Okuryazarlı Becerisine İlişkin Bağımsız Örneklem T-Testi Sonuçlan

\begin{tabular}{lcccccc}
\hline Bilgisayar/Tablet & $\mathbf{N}$ & $\overline{\boldsymbol{X}}$ & Ss & Sd & $\mathbf{t}$ & $\mathbf{p}$ \\
\hline Var & 588 & 80,46 & 12,39 & 740 & 7,130 &, $000^{*}$ \\
\hline Yok & 154 & 72,37 & 13,04 & & & \\
\hline${ }^{*} \mathrm{p}<.01$ & & & & & &
\end{tabular}

Tablo 18 'deki test sonuçları, evlerinde bilgisayar veya tablet olan öğrencilerin dijital okuryazarlık düzeyinin $(\bar{X}=80,46)$ evlerinde bilgisayar veya tablet olmayan öğrencilerin dijital okuryazarlık düzeyinden $(\bar{X}=72,37)$ anlamlı ölçüde yüksek olduğunu göstermektedir $\left(\mathrm{t}_{(740)}=7,130, \mathrm{p}<.01\right)$. Evlerinde bilgisayar veya tablet olması durumunun, öğrencilerin dijital okuryazarlık puanlarını anlamlı bir şekilde etkilediği görülmektedir.

\section{Evlerinde İnternet Bağlantısı Olması Durumuna Göre Öğrencilerin Dijital Okuryazarlık Becerilerine İlişkin Bulgular}

Tablo 19

Evlerinde İnternet Bağlantısı Olması Durumuna Göre Öğrencilerin Dijital Okuryazarlık Becerisine İlişkin Bağımsız Örneklem T-Testi Sonuçlan

\begin{tabular}{lcccccc}
\hline İnternet bağlantısı & \multirow{2}{*}{} & \multicolumn{1}{c}{ S } & Sd & t & p \\
\hline Var & 444 & 81,10 & 12,77 & 740 & 6,106 &, $000^{*}$ \\
\hline Yok & 298 & 75,32 & 12,44 & & & \\
\hline${ }^{*} \mathrm{p}<.01$ & & & & &
\end{tabular}


Tablo 19'dan; evlerinde internet bağlantısı olan öğrencilerin dijital okuryazarlık düzeyinin $(\bar{X}=81,10)$, evlerinde internet bağlantısı olmayan öğrencilerin dijital okuryazarlık düzeyinden $(\bar{X}=75,32)$ anlamlı ölçüde yüksek olduğu görülmektedir $\left(\mathrm{t}_{(740)}=6,106, \mathrm{p}<.01\right)$. Evlerinde bilgisayar veya tablet olmas1 durumunun öğrencilerin dijital okuryazarlık puanlarına anlamlı bir şekilde etkilediği görülmektedir.

\section{1. İnternete Bağlanma Sıklığına Göre Öğrencilerin Dijital Okuryazarlık Becerilerine İlişkin Bulgular}

Tablo. 20

İnternete Bağlanma Sıkhı̆ına Göre Öğrencilerin Dijital Okuryazarlık Becerisine İlişkin Betimleyici İstatistikler

\begin{tabular}{lccc}
\hline $\begin{array}{l}\text { İnternete bağlanma } \\
\text { s1klı̆ğ }\end{array}$ & $\mathbf{N}$ & $\overline{\boldsymbol{X}}$ & Ss \\
\hline Hiç (1) & 111 & 71,89 & 12,39 \\
Ayda 1 kez (2) & 64 & 74,04 & 13,14 \\
Haftada 1 kez (3) & 156 & 78,26 & 11,96 \\
Haftada 2-3 kez (4) & 259 & 81,77 & 11,78 \\
Her gün (5) & 152 & 81,23 & 13,73 \\
Toplam & $\mathbf{7 4 2}$ & $\mathbf{7 8 , 7 8}$ & $\mathbf{1 2 , 9 4}$ \\
\hline
\end{tabular}

Tablo 20'den görüldüğü üzere dijital okuryazarlık becerisi puanlarının ortalamaları; internete hiç bağlanmayan öğrencilerin 71,89, ayda 1 kez bağlanan öğrencilerin 74,04, haftada 1 kez bağlanan öğrencilerin 78,26, haftada 2-3 kez bağlanan öğrencilerin 81,77 ve her gün bağlanan öğrencilerin 81,23 tür. İnternete haftada 2-3 kez ve her gün bağlanan öğrencilerin dijital okuryazarlık becerisi puanlarının yüksek olduğu görülmüştür. İnternete bağlanma sıklığına göre öğrencilerin dijital okuryazarlık becerisine ilişkin tek yönlü ANOVA testi sonuçları Tablo 21'de gösterilmiştir.

Tablo 21

İnternete Bă̆lanma Sıklı̆̆ına Göre Öğrencilerin Dijital Okuryazarlık Becerisine İlişkin Tek Yönlü ANOVA Testi Sonuçları

\begin{tabular}{|c|c|c|c|c|c|c|}
\hline Varyansın Kaynağı & $\begin{array}{c}\text { Kareler } \\
\text { Toplamı }\end{array}$ & Sd & $\begin{array}{c}\text { Kareler } \\
\text { Ortalamas1 }\end{array}$ & $\mathbf{F}$ & p & Tukey \\
\hline Gruplar arası & 9977,343 & 4 & 2494,336 & 16,085 &, $000^{*}$ & $1<3,4,5$ \\
\hline Grup içi & 114289,288 & 737 & 155,074 & & & $2<4,5$ \\
\hline Toplam & 124266,631 & 741 & & & & $3<4$ \\
\hline
\end{tabular}

${ }^{*} \mathrm{p}<.01$

Öğrenci dijital okuryazarlık becerisi düzeylerinin, internete bağlanma sıklı̆̆ına göre anlamlı olarak değiştiği görülmektedir $\left(\mathrm{F}_{(4-737)}=16,085, \mathrm{p}<.01\right)$. Farkın kaynağını tespit etmek için yapılan Tukey testi; $1-3 / 4 / 5,2-4 / 5$ ve 3-4 grupları arasındaki farkın anlamlı olduğunu göstermiştir. İnternete bağlanma sıklı̆̆ının, öğrencilerin dijital okuryazarlık becerisi üzerinde etkili olduğu söylenebilir. 


\section{Sonuç ve Tartışma}

Çalışmada öğrencilerin genel olarak dijital okuryazarlık becerisi puanlarının yüksek olduğu belirlenmiştir. Bu durum, günümüzdeki çocukların dijital dünyayla iç içe yaşaması, çoğu öğrencinin evinde ve okullarda dijital teknolojilerin kullanılması, birçok dersin içeriğinde dijital okuryazarlık becerilerine yer verilmesi gibi durumlarla açıklanabilir. Dönmez (2019), ortaöğretim öğrencilerinin dijital okuryazarlık durumlarının iyi düzeyde olduğunu belirtmiş̧ir. Yıldırım (2015), temel eğitim öğrencilerinin teknoloji kullanım becerilerinin iyi düzeyde olduğunu belirtmiştir. Kurt, Çoklar, Kılıççer ve Yıldırım (2008) ise çalışmalarında öğrencilerin ortalama eğitim teknolojisi standartlarına sahip oldukları sonucunu ortaya koymuşlardır. Benzer şekilde Tuti (2005) de öğrencilerin bilgisayar öz yeterlik algılarını orta derece olarak tespit etmiştir.

Öğrencilerin yerleşim yerine göre dijital okuryazarlık becerilerine bakıldığında; il merkezinde yaşayan öğrencilerin dijital okuryazarlık becerisi puan ortalamalarının il merkezine bağlı belde ve ilçe merkezinde yaşayan öğrencilerinkinden daha yüksek olduğu görülmüştür. Öğrencilerin ikamet ettikleri yerlerin, öğrencilerin dijital okuryazarlık becerisi üzerinde etkili olduğu belirlenmiştir. Bu durum, öğrencilerin il merkezinde dijital teknolojilere daha kolay ulaşma imkânlarına sahip olmasıyla açıklanabilir. Kılıç ve Yıldırım (2008) da benzer bir şekilde kentlerde yaşayan öğrencilerin ‘Bilgi ve İletişim Teknolojileri' ni (BİT) kullanım düzeylerinin, kırsalda yaşayan öğrencilerden daha yüksek olduğu sonucuna ulaşmışlardır.

Cinsiyete göre öğrencilerin dijital okuryazarlık puanlarının birbirine yakın olduğu ve dijital okuryazarlık puanlarının cinsiyete göre anlamlı olarak değişmediği tespit edilmiştir. Bu durum, günümüzde dijital teknolojilerin kız ya da erkek fark etmeksizin bütün öğrencilerin hayatlarında önemli bir şekilde yer almasıyla açıklanabilir. Ayrıca, okullarda dijital okuryazarlık becerisini geliştirmek için çeşitli etkinliklerin yapılmasıyla beraber kız ve erkek öğrenciler bu konuda benzer gelişim sağlamış olabilir. Yapılan farklı çalışmalarda dijital okuryazarlık, bilgisayar öz yeterlik algısı, teknoloji kullanım düzeyleri, BİT okuryazarlığı, teknolojiye yönelik tutum, teknoloji kullanım yeterlikleri, eğitim teknolojisi standartları kullanım becerileri, BiंT'ten yaralanma ve bilgisayara erişme konularında cinsiyete göre bir farklılığın olmadığı sonucuna ulaşılmıştır (Seferoğlu ve Akbıyık, 2005; Tuti, 2005; Özçelik ve Adile Aşkım Kurt, 2007; Koch, Müller ve Sieverding, 2008; Kurt, Çoklar, Kılıçer ve Yıldırım, 2008; Özmusul, 2008; Şerefhanoğlu, Nakiboğlu ve Gür, 2008; Çetin, Çalışkan ve Menzi, 2012; Aşıcı ve Usluel, 2013; Yılmaz ve Ersoy, 2014; Dağtaş, Yıldırım, Başoğlu, Kaplan ve Taş, 2015; Öztürk, 2015; Dönmez, 2019). Özerbaş ve Kuralbayeva (2018) ve Yonpar (2019), öğretmen adaylarının kendilerine ilişkin dijital okuryazarlık düzeylerinin erkeklerin lehine olduğu sonucuna ulaşmışlardır. Erkek öğrencilerin bilişim teknolojileri yeterlik algılarının (Çetinkaya, 2008) ve bilgisayara ilişkin öz yeterlik algılarının (Deryakulu, 2007) kız öğrencilere göre anlamlı olarak daha yüksek olduğu sonucuna ulaşmıştır. Tsai, Lin ve Tsai (2001) interneti kullanma konusunda, erkek öğrencilerin kız öğrencilere göre daha fazla olumlu duygu, daha az kaygı ve daha fazla güvene sahip olduklarını ortaya koymuşlardır. Burge (2001), dördüncü ve beşinci sınıf öğrencilerinin teknoloji kullanım davranışlarında kız öğrencilerin lehine anlamlı farklılıklar olduğunu gözlemlemiştir. 
Kardeş sayısına göre öğrencilerin dijital okuryazarlık becerisi puanlarına bakıldığında, genel olarak kardeş sayısı arttıkça dijital okuryazarlık puanlarının düştügü görülmüştür. Bu nedenle kardeş sayısının, dijital okuryazarlık becerisi puanlarının üzerinde önemli bir değişken olduğu sonucuna ulaşılmıştır. Bu durum, kardeş sayısı arttıkça kardeşlerin birbirleriyle vakit geçirme süresinin artabileceği ve bu nedenle dijital teknolojilere daha az vakit ayırabileceği varsayımı ile açıklanabilir.

Anne eğitim durumunun, öğrencilerin dijital okuryazarlık becerisi puanlarının üzerinde etkili olduğu belirlenmiştir. Anne eğitim durumu artıkça dijital okuryazarlık becerisinin de arttığı ortaya çıkmıştır. Günümüzde eğitim ve dijital hayat gittikçe birbirlerinden daha fazla etkilenmeye başlamıştır. Bu nedenle, anne eğitim düzeyi arttıkça annenin dijital teknolojiler ile ilgili daha fazla eğitim alacağ1 düşünülebilir. Bu bakımdan, eğitim düzeyi yüksek olan annenin çocuğunun dijital okuryazarlık düzeyinin daha yüksek olması beklenen bir durumdur. Farklı çalışmalarda da benzer sonuçlara ulaşılmıştır. Anne eğitim seviyesi yükseldikçe öğrencilerin; dijital vatandaşlık seviyesinin (Öztürk, 2015), BİT okuryazarlık düzeyinin (Aşıcı ve Usluel, 2013), teknoloji kullanım becerilerinin (Yıldırım, 2015), eğitim teknolojisi standartları kullanım becerilerinin (Kurt, Çoklar, Kılıççer ve Yıldırım, 2008), bilişim teknolojileri yeterlik algılarının (Çetinkaya, 2008), teknoloji kullanım yeterliklerinin (Kuzu vd., 2008) ve bilişim teknolojilerinden yararlanmanın düzeylerinin (Özden ve Fırat, 2013) de yükseldiği sonucu ortaya konulmuştur.

Baba eğitim durumunun öğrencilerin dijital okuryazarlık becerisi puanlarının üzerinde etkili olduğu görülmektedir. Baba eğitim durumu yükseldikçe dijital okuryazarlık becerisinin de arttı̆̆1 görülmüştür. Anne eğitim düzeyinde olduğu gibi baba eğitim düzeyi de arttıkça babanın dijital teknolojiler ile ilgili daha fazla eğitim alması beklenir. Dolayısıyla, eğitim düzeyi yüksek olan babanın çocuğunun dijital okuryazarlık düzeyinin daha yüksek olması beklenen bir durumdur. Farklı araştırmalarda da öğrencilerin baba eğitim düzeyi yükseldikçe; BİT okuryazarlıklarının (Aşıcı ve Usluel, 2013), dijital vatandaşlık seviyelerinin (Öztürk, 2015), teknoloji kullanım düzeylerinin (Yıldırım, 2015), bilişim teknolojileri yeterlik algılarının (Çetinkaya, 2008) ve bilişim teknolojilerinden yararlanma düzeylerinin (Özden ve Fırat, 2013) de arttığı sonucuna ulaşılmıştır. Kurt, Çoklar, Kılıççer ve Yıldırım (2008) ise baba eğitim durumunun, öğrencilerin eğitim teknolojisi standartları seviyelerini etkilemediği sonucuna ulaşmıştır.

Anne mesleğinin, öğrencilerin dijital okuryazarlık becerisi puanlarının üzerinde etkili olduğu tespit edilmiştir. Annesi memur olan öğrencilerin en yüksek, annesi işçi olan öğrencilerin en düşük dijital okuryazarlık becerisi puan ortalamalarına sahip olduğu görülmüştür. Bu durum, günümüzde neredeyse bütün memurların işlerini dijital teknolojiler üzerinden yürütmesi ve bu konuda çocuklarına destek olmalarıyla açıklanabilir. Yılmaz ve Ersoy (2014), beşinci sınıfa devam eden öğrencilerden annesi memur olanların BİT okuryazarlık düzeylerinin diğer öğrencilerden daha yüksek olduğu sonucuna ulaşmışlardır. Özmusul (2008) ile Özden ve Firat (2013) annesi memur olan öğrencilerin, annesi işçi, serbest meslek ve diğer meslek sahibi olan öğrencilerden daha fazla bilişim teknolojilerinden yararlandıklarını belirtmişlerdir.

Baba mesleğinin, öğrencilerin dijital okuryazarlık becerisi puanlarının üzerinde etkili olduğu belirlenmiştir. Babası memur olan öğrencilerin en yüksek, babası işçi olan öğrencilerin en düşük dijital okuryazarlık becerisi puan ortalamalarına sahip 
olduğu görülmüştür. Babası memur olan çocukların dijital okuryazarlık düzeylerinin daha yüksek çıkması memurların işlerinde çoğunlukla dijital ortamda çalışmaları ve deneyimlerini çocuklarına aktarmalarıyla açıklanabilir. Yılmaz ve Ersoy (2014), beşinci sınıf öğrencilerinden babası memur olan öğrencilerin BİT okuryazarlık düzeylerinin diğer öğrencilerden daha yüksek olduğuna ulaşmışlardır. Özmusul (2008) ile Özden ve Fırat (2013) öğrencilerin babası memur olanların, babası; işçi, serbest meslek ve diğer meslek sahibi olan öğrencilere göre bilişim teknolojilerinden daha fazla faydalandıklarını belirtmişlerdir.

Sosyal bilgiler dersi karne notunun, öğrencilerin dijital okuryazarlık becerisi üzerinde önemli bir etken olduğu belirlenmiştir. Öğrencilerin, sosyal bilgiler dersi karne notu arttıkça dijital okuryazarlık becerisi puanlarının da artmış olduğuna ulaşılmıştır. Bu durum, 2018 SBDÖP'te dijital okuryazarlık becerisinin yer alması, bu beceriyi öğrencilere kazandırmak için kazanım ve etkinliklere yer verilmesi, dolayısıyla öğrencilerin bu beceriyle ilgili eğitim almasıyla açıklanabilir. Haliyle, sosyal bilgiler dersi karne notu yüksek olan öğrencilerin bu beceriyle ilgili kazanımları daha iyi edinmesi beklenen bir durumdur. Özmusul (2008) da benzer bir şekilde öğrenci notları arttıkça öğrencilerin bilişim teknolojilerinden yararlanma düzeylerinin de arttığı sonucuna ulaşmıştır.

Evlerinde bilgisayar veya tablet olması durumunun, öğrencilerin dijital okuryazarlık puanlarını etkilediği görülmüştür. Evlerinde bilgisayar veya tablet olan öğrencilerin, evlerinde bilgisayar veya tablet olmayan öğrencilerin dijital okuryazarlık düzeyinden yüksek olduğu sonucuna ulaşılmıştır. Evlerinde tablet ya da bilgisayar olan öğrencilerin dijital ortamda daha fazla zaman geçirmesi ve daha fazla deneyim yaşaması nedeniyle bu öğrencilerin dijital okuryazarlık becerisi daha fazla gelişebilir. Yıldırım (2015) da evlerinde bilgisayar olan öğrencilerin teknoloji kullanım yeterlik düzeylerinin, evlerinde bilgisayar olmayanlara göre daha yüksek olduğunu belirlemiştir. Kuhlemeier ve Hemker (2007), öğrencilerin evlerinde bilgisayar kullanımları ile teknoloji kullanım becerilerinin oldukça ilişkili olduğuna ulaşmışlardır. Kurt, Çoklar, Kılıççer ve Yıldırım (2008), öğrencilerin bilgisayara sahip olmalarının, eğitim teknolojisi standartları kullanım becerilerinin gelişmesinde oldukça etkili olduğu sonucuna ulaşmışlardır. Çetinkaya (2008), evlerinde bilgisayara sahip olan öğrencilerin, bilişim teknolojileri yeterlik algılarının yüksek olduğunu tespit etmiştir. Vekiri (2010) ise ortaokul beşinci ve altıncı sınıflara devam eden öğrencilerin evlerinde BİT erişiminin olması ile BİT kullanımları arasında bir ilişki olmadığı sonucuna ulaşmıştır.

Evlerinde internet bağlantısı olan öğrencilerin dijital okuryazarlık düzeyinin, evlerinde internet bağlantısı olmayan öğrencilerin dijital okuryazarlık düzeyinden anlamlı ölçüde yüksek olduğu belirlenmiştir. Evlerinde internet bağlantısı olması durumunun öğrencilerin dijital okuryazarlık puanlarını anlamlı bir şekilde etkilediği görülmüştür. Evlerinde internet bağlantısı olan öğrencilerin çevrimiçi olarak dijital ortamda daha fazla deneyim yaşamaları nedeniyle dijital okuryazarlık düzeyleri internet bağlantısı olmayanlara göre daha yüksek olabilir. Farklı çalışmalarda evlerinde internet erişimi olan öğrencilerin; teknoloji kullanım becerilerinin gelişimi (Kuhlemeier ve Hemker, 2007), eğitim teknolojisi standartları kullanım becerilerinin gelişmesi (Kurt, Çoklar, Kılıççer ve Yıldırım, 2008) ve teknoloji kullanım yeterlikleri (Yıldırım, 2015) konularında evlerinde internet bağlantısı olmayan öğrencilerden 
daha yüksek seviyede olduğu görülmüştür. Evlerinde internet bağlantısı olan öğretmen adayları dijital okuryazarlık, teknoloji yeterliliği ve teknolojiye yönelik tutumları konusunda kendilerini daha yetkin hissettikleri belirtilmiştir (Çetin, Çalışkan ve Menzi, 2012).

İnternete bağlanma sıklığının, öğrencilerin dijital okuryazarlık becerisi düzeyleri üzerinde etkili olduğu belirlenmiştir. Genel olarak öğrencilerin, internete bağlanma sıklığı arttıkça dijital okuryazarlık becerisi düzeylerinin de arttı̆̆ sonucuna ulaşılmıştır. Öğrencilerin çevrimiçi ortamda daha fazla vakit geçirmeleri, onların dijital ortamda daha fazla deneyim yaşamalarına ve daha fazla öğrenme imkânına sahip olmalarını sağlayabilir. Dolayısıyla da bu öğrencilerin dijital okuryazarlıkları diğer öğrencilere göre daha fazla gelişebilir. Yapılan farklı çalışmalarda da benzer sonuçlara ulaşılmıştır. Yıldırım (2015), öğrencilerin interneti kullanma sıklığı artıkça teknoloji kullanım becerilerinin arttığı sonucuna ulaşmıştır. Tsai, Lin ve Tsai (2001), interneti sık kullanan öğrencilerin, interneti daha az kullanan öğrencilere göre internete karşı daha olumlu tutum sergilediklerini belirtmiştir. Özerbaş ve Kuralbayeva (2018), öğretmen adaylarının internet kullanma sıklıkları arttıkça dijital okuryazarlık konusunda kendilerini daha yeterli olarak gördükleri sonucuna ulaşmışlardır. Çetin, Çalışkan ve Menzi (2012), öğretmen adaylarından interneti daha sık kullananların kendilerini teknoloji alanında diğerlerine göre daha yeterli gördüklerini belirtmişlerdir. Acar (2015) ise ebeveynlerin interneti kullanma sıklığı arttıkça dijital okuryazarlıklarının da arttığını belirtmiştir.

\section{Öneriler}

Çalışma sonuçlarına göre ortaokul beşinci sınıf öğrencilerinin dijital okuryazarlık becerilerinin iyi bir düzeyde olduğu görülmektedir. Bununla birlikte, bireylerin dijital dünyada daha fazla yer almaya başlaması nedeniyle SBDÖP'te dijital okuryazarlık becerisine farklı sinıf düzeylerinde de yer verilebilir. Sosyal bilgiler ders kitaplarında her sınıf düzeyinde dijital okuryazarlık becerisini geliştirebilecek etkinliklere daha fazla yer verilebilir. Ayrıca, hem 'Bilim, Teknoloji ve Toplum' öğrenme alanı işlenirken hem de dijital okuryazarlık becerisi ile ilgili etkinlikler yapılırken bilişim teknolojileri ve yazılım dersi öğretmeni ile disiplinlerarası bir şekilde çalışılabilir, bilişim teknolojileri ve yazılım dersi laboratuvarı kullanılabilir.

Çeşitli değişkenlere göre öğrencilerin dijital okuryazarlık becerisinin farklılaştığı görülmektedir. Birçok değişkenin okul dışı ortamlarda değiştirilmesinin zor olduğunu düşünürsek, okul ortamında bu değişkenlerin etkisini en aza indirilebilmesi için (her öğrenciye eşit fursatlar vermek, evlerinde bilgisayar ve internete ulaşamayacak öğrencilere okullarda bu imkânı sunmak, ders materyallerinin çeşitli değişkenlerin etkisini en aza indirebilecek şekilde oluşturulması, planlamanın bu duruma göre yapılması gibi) çeşitli önlemler alınabilir.

Çalışmada öğrencilerin; dijital okuryazarlık becerisi düzeyleri nicel olarak incelenmiştir. Farklı çalışmalarda bu beceri nitel olarak da incelenebilir.

\section{Kaynakça}

Acar, Ç. (2015). Anne ve babalarm ilkokul ortaokul ve lise öğrencisi çocuklarn ile kendilerinin dijital okuryazarlıklarına ilişkin görüşleri (Yayımlanmamış yüksek lisans tezi). T.C. Ankara Üniversitesi Eğitim Bilimleri Enstitüsü, Ankara. 
Altun, A. (2003). Öğretmen adaylarının internete yönelik tutumları. Eğitim ve Bilim, 28(127), 3-9.

Altunışık, R., Coşkun, R., Bayraktaroğlu, S. ve Yıldırım, E. (2005). Sosyal Bilimlerde Araştırma Yöntemleri SPSS Uygulamalı, Adapazarı: Sakarya Kitapevi.

Aşıcı, T. B. ve Usluel, Y. K. (2009). Sayısal uçurumun üniversite öğrencilerinin demografik özelliklerine göre incelenmesi. Hacettepe Üniversitesi Ĕ̆itim Fakültesi Dergisi, 44(44), 73-84.

Avc1, E. K. ve Faiz, M. (2018). 4. ve 5. sınıf sosyal bilgiler ders kitapları "etkin vatandaşlık" öğrenme alanında yer alan becerilerin ve değerlerin incelenmesi. Uluslararası Sosyal Bilgilerde Yeni Yaklaşımlar Dergisi (IJONASS), 2(1), 1-21.

Blikstad-Balas, M. (2015). Digital literacy in upper secondary school-what do students use their laptops for during teacher instruction?. Nordic Journal of Digital Literacy, 10, 122-137.

Bozkurt, F. ve Çoşkun, D. (2018). 21. yy okuryazarlığı: Öğretmen adaylarının medya algılarına genel bir bakış. Erciyes İletişim Dergisi, 5(4), 493-511. https:/ / doi.org/10.17680/erciyesiletisim.381046

Buckingham, D. (2010) Defining Digital Literacy. Bachmair, B. (Ed.), Medienbildung in neuen kulturräumen (s. 59-71) içinde. VS Verlag für Sozialwissenschaften. https:/ / doi.org/10.1007/978-3-531-92133-4_4

Burge, K.B. (2001). UCI computer arts: Building gender equity while meeting iste nets. Paper presented at the National Educational Computing Conference, "Building on the future", Chicago.

Büyüköztürk, Ş. (2008). Sosyal Bilimler İçin Veri Analizi El Kitabı, 9. bs., Ankara: Pegem Akademi.

Creswell, W. J. (2016). Araştırma Deseni: Nitel, Nicel ve Karma Yöntem Yaklaşımları. Selçuk Beşir Demir (Çev. Edt.). Ankara: Eğiten Kitap.

Çetin, O., Çalışkan, E. ve Menzi, N. (2012). Öğretmen adaylarının teknoloji yeterlilikleri ile teknolojiye yönelik tutumları arasındaki ilişki. İlköğretim Online, 11(2), 273-291.

Çetinkaya, Y. (2008). Information and communication technology education in primary schools: students' competencies, attitudes and needs (Yayımlanmamış yüksek lisans tezi). Orta Doğu Teknik Üniversitesi Sosyal Bilimler Enstitüsü, Ankara.

Çokluk Ö., Şekercioğlu, G. ve Büyüköztürk, Ş. (2012). Sosyal Bilimler İçin Çok Değişkenli İstatistik SPSS ve LISREL Uygulamaları, 2.bs., Ankara: Pegem Akademi.

Dağtaş, A., Yıldırım, Ö. K., Başoğlu, N., Kaplan, T. ve Taş, H. (2015). Türkçe öğretimi araştırma ve uyulama merkezlerinde Türkçe öğrenen yabancı öğrencilerin bilgisayar okuryazarlığı düzeyleri: Gaziantep, Bolu örneklemi. Route Educational and Social Science Journal, 2(1), 32-49. https:/ / doi.org/10.17121/ressjournal.220

Deryakulu, D. (2007). Seçmeli bilgisayar dersi ve bilgisayar öz-yeterlik algısının 8. sinıf öğrencilerinin seçmek istedikleri mesleklerle ilişkisi. Ankara Üniversitesi Eğitim Bilimleri Fakültesi Dergisi, 40(2), 1-22. https:/ / doi.org/10.1501/Egifak_0000000146 
Dönmez, G. (2019). Lise öğrencilerinin bilgi güvenliği farkındahı̆̆ ile dijital okuryazarlı̆̆ı arasındaki ilişkinin incelenmesi (Yayımlanmamış Yüksek Lisans Tezi). Hacettepe Üniversitesi Eğitim Bilimleri Enstitüsü, Ankara.

Gelen, İ. (2017). P21-program ve öğretimde 21. yüzy1l beceri çerçeveleri (ABD Uygulamaları). Disiplinlerarası Eğitim Araştırmaları Dergisi, 1(2), 15-29.

Gilster, P. (1997). Digital Literacy, New York: Wiley Computer Pub.

Gömleksiz, M. N. ve Cüro, E. (2011). Sosyal bilgiler dersi öğretim programının toplumsal ihtiyaçları karşılama düzeyine ilişkin öğretmen görüşleri. Millî Ĕğitim Dergisi, 190, 145-167.

Hamutoğlu, N. B., Güngören, Ö. C., Uyanık, G. K. ve Erdoğan, D. G. (2017). Dijital okuryazarlık ölçeği: Türkçeye uyarlama çalışması. Ege Ĕ̆itim Dergisi, 18(1), 408-429. https:// doi.org/10.12984/egeefd.329432

Karabacak, Z. İ. ve Sezgin, A. A. (2019). Türkiye'de dijital dönüşüm ve dijital okuryazarlik. Türk İdare Dergisi, 91(488), 319-343.

Karasar, N. (2017). Bilimsel Araştırma Yöntemi: Kavramlar, İlkeler, Teknikler, 32. bs., Ankara: Nobel Akademik Yayıncılık.

Kıncal, R. Y. (2017). Bilimsel Araştırma Yöntemleri, 5.bs., Ankara: Nobel Akademik Yayıncilik.

Kılıç, E. and Yıldırım, Z. (2008). Understanding Net Generation: Students' Profiles on Using Information and Communication Technologies and Their Preferences of Playing Games. In The European Conference on Educational Research (ECER 2008), From Teaching to Learning.

Knobel, M. and Lankshear, C. (2006). Digital literacy and digital literacies: policy, pedagogy and research considerations for education. Nordic Journal of Digital Literacy, 1(01), 12-24.

Koch, S. C., Müller, S. M. and Sieverding, M. (2008). Women and computers. Effects of stereotype threat on attribution of failure. Computers and Education, 51(4), 1795-1803. https:/ / doi.org/10.1016/j.compedu.2008.05.007

Kuhlemeier, H. and Hemker, B. (2007). The impact of computer use at home on students' Internet skills. Computers and Education, 49(2), 460-480. https:/ / doi.org/10.1016/j.compedu.2005.10.004

Kurt, A. A., Çoklar, A. N., Kılıçer, K. and Yıldırım, Y. (2008). Evaluation of the skills of K-12 students regarding the national educational technology standards for students (NETS* S) in Turkey. Online Submission, 7(3), 9-15.

Kuzu, A. vd. (2008). İnternet kullanımı ve aile (internet use and family). Ankara: T. C. Başbakanlık Aile ve Sosyal Araştırmalar Genel Müdürlüğü (Prime ministry of Turkey, General Directorate of Family and Social Research) Bilim Serisi: 133.

Maden, S., Maden, A. ve Banaz, E. (2018). Ortaokul 5. sınıf Türkçe ders kitaplarının dijital okuryazarlık bağlamında değerlendirilmesi. Uluslararası Sosyal Araştırmalar Dergisi, 11(55), 685-695. https:/ / doi.org/10.17719/jisr.20185537239

Malkoç, E. (2018) Bilgisayar ve internet kullanımının sosyal bilgiler öğretiminde başarıya ve kalıcılı̆̆a etkisi (Yayımlanmamış Yüksek Lisans Tezi). Dokuz Eylül Üniversitesi Eğitim Bilimleri Enstitüsü, İzmir.

Martin, A. (2005). DigEuLit - a european framework for digital literacy: a progress report. Journal of eLiteracy, 2, 130-136. 
Martin, A. and Grudzieci, J. (2006). DigEuLit: Concepts and tools for digital literacy development. Innovation in Teaching and Learning in Information and Computer Sciences, 5(4), 249-267. https://doi.org/10.11120/ital.2006.05040249

Meyers, E. M., Erıckson, I. and Small, R. V. (2013). Digital literacy and informal learning environments: an introduction. Learning, Media and Technology, 38(4), 355-367. https:/ / doi.org/10.1080/17439884.2013.783597

Mustafa Ö. ve Fırat E. A. (2013). İlköğretim öğrencilerinin bilgi iletişim teknolojilerinden yararlanma düzeyleri ve bilimsel süreç becerileri arasındaki ilişki. Adıyaman Üniversitesi Sosyal Bilimler Enstitüsü Dergisi, 15, 1-28. https:/ / doi.org/10.14520/adyusbd.683

Özçelik, H. ve Kurt, A. A. (2007). İlköğretim öğretmenlerinin bilgisayar özyeterlikleri: Balıkesir ili örneği. İlköğretim Online, 6(3), 441-451.

Özerbaş, M. A. ve Kuralbayeva, A. (2018). Türkiye ve Kazakistan öğretmen adaylarının dijital okuryazarlık düzeylerinin incelenmesi. MSKU Ĕ̆itim Fakültesi Dergisi, 5(1), s. 16-25. https:/ / doi.org/10.21666/muefd.314761

Özmusul, M. (2008). İlköğretim ikinci kademe öğrencilerinin bilgi ve iletişim teknolojilerinden yararlanma düzeylerinin incelenmesi (Yayımlanmamış yüksek lisans tezi). T.C. Gaziantep Üniversitesi Sosyal Bilimler Enstitüsü, Gaziantep.

Öztürk, M. (2015). Ortaokul öğrencilerinin dijital vatandaşlık düzeyleri (Yayınlanmamış yüksek lisans tezi). T.C. Kastamonu Üniversitesi Sosyal Bilimler Enstitüsü, Kastamonu.

Pala, Ş. M. (2019). Ortaokul 5. sını öğrencilerinin sosyal bilgiler dersi bilim teknoloji ve toplum öğrenme alanına ilişkin akademik başarı ve becerilerinin incelenmesi (Yayımlanmamış doktora tezi). Erzincan Binali Yıldırım Üniversitesi Sosyal Bilimler Enstitüsü, Erzincan.

Ribble, M. (2011). Digital Citizenship in Schools. Washington, DC: International Society for Technology in Education (ISTE).

Seferoğlu, S. S. ve Akbıyık, C. (2005). İlköğretim öğretmenlerinin bilgisayara yönelik öz-yeterlik algıları üzerine bir çalışma. Ĕ̆itim Araştırmaları Dergisi, 19, 89-101.

Stripling, B. (2010). Teaching students to think in the digital environment: digital literacy and digital inquiry. School Library Monthly, 26(8), 16-19.

Şerefhanoğlu, H., Nakiboğlu, C. ve Gür, H. (2008). İlköğretim ikinci kademe öğrencilerinin bilgisayara yönelik tutumlarının çeşitli değişkenler açısından incelenmesi: Balıkesir örneği. İlköğretim Online, 7 (3), 785-799.

Tavakol, M. and Dennick, R. (2011). Making sense of Cronbach's Alpha. International Journal of Medical Education, 2, 53-55. https:/ / doi.org/10.5116/ijme.4dfb.8dfd

T.C. Milli Eğitim Bakanlığı. (2018). Sosyal Bilgiler Dersi Öğretim Programı (İlkokul ve Ortaokul 4, 5, 6 ve 7. Siniflar), Ankara.

Tsai, C. C., Lin, S. S. and Tsai, M. J. (2001). Developing an internet attitude scale for high school students. Computers and Education, 37(1), 41-51. https:/ / doi.org/10.1016/S0360-1315(01)00033-1

Tuti, S. (2005). Eğitimde bilişim teknolojileri kullanımı performans göstergeleri, öğrenci görüşleri ve öz-yeterlik algılarının incelenmesi (Yayımlanmamış yüksek lisans tezi). Hacettepe Üniversitesi Fen Bilimleri Enstitüsü, Ankara. 
Ünal, D. P. (2017). Bir öğretim programındaki dijital vatandaşlık öğeleri ve ortaöğretim öğrencilerinin dijital vatandaşlik ögelerine sahip olma durumlar. Karaelmas Eğitim Bilimleri Dergisi, 5, 180-195.

Vekiri, I. (2010). Socioeconomic differences in elementary students' ICT beliefs and out-of-school experiences. Computers and Education, 54(4), 941-950. https:/ / doi.org/10.1016/j.compedu.2009.09.029

Yaşar, Ç. (2019). BÖTE öğretmen adaylarının kariyer eğilimlerinin, sosyal medyaya ilişkin görüşlerinin ve dijital okuryazarlı beceri düzeylerinin incelenmesi (Yayımlanmamış yüksek lisans tezi). T.C. Balıkesir Üniversitesi Fen Bilimleri Enstitüsü, Balıkesir.

Yontar, A . (2019). Öğretmen adaylarının dijital okuryazarlık düzeyleri. Ana Dili Ĕ̆itimi Dergisi, 7 (4) , 815-824. https://doi.org/10.16916/aded.593579

Yıldırım, Y. (2015). İlköğretim öğrencilerinin teknoloji kullanım yeterlikleri ve teknoloji kullanımını etkileyen faktörler. Eskişehir Ziya Gökalp İlkokulu, 39(87), 12-18.

Yılmaz, F., ve Ersoy, A. (2014). Besinci sınıf öğrencilerinin BİT erişim olanakları ve BİT okuryazarlık düzeyleri arasındaki dijital bölünme. Journal of Educational Science, 2(2), 16-32.

\section{Summary}

\section{Introduction}

With the change in reading and writing skills originated by the advances in the digital technologies, the digital literacy skill has begun to be one of the basic skills that each individual should have (Maden, Maden and Banaz, 2018). It has become a significant necessity to know how, why and how much we should use the technology. In the digital technology digital literacy has become an important element affecting our daily lives, thanks to its guidance (Özerbaş and Kuralbayeva, 2018).

Today, with the spread of the Internet, students have become more involved in the digital world (Bozkurt and Çoşkun, 2018). With digitalization in the field of education, digital literacy skill has become a skill that students should acquire (Stripling, 2010; Sönmez and Gül, 2018). Therefore, discussions on digital technology and education focus on the types of competence and understanding that individuals need to use technology effectively and critically (Buckingham, 2010).

With the effective use of digital technologies and social networks, skills and competencies related to the digital world have begun to be included in the curricula (Gelen, 2017). In-class and extracurricular activities were included in the curricula to improve digital citizenship competencies (MoNE, 2018). In this regard, the digital literacy skill in the SSLC, aiming to educate and to train active citizens who are involved in life and adapted to today's conditions. The digital literacy skill was included in the 5th grade SSLC as a skill that is expected to be gained in the 'Science, Technology and Community' learning field. Also, this skill was emphasized in the program, within the scope of competencies, goals, issues to be considered and some of the gains. 


\section{Problem Situation}

What is the level of digital literacy skills of fifth-grade students?

Do the digital literacy skills of the students differ according to the place of residence, gender, number of siblings, parents' education level, parent profession, social studies course report mark, having computer or tablet at home, having an internet connection at home and frequency of connecting to the internet?

\section{Research Purpose}

Several skills were included in the 2018 SSLC. One of these skills is digital literacy skill. With the digitalizsation, students' acquiring these skills has gained great significance. In this study, it was aimed to investigate the digital literacy skills of secondary school 5 th grade students in terms of various variables.

\section{Method}

This study is a descriptive research in which the relational survey model was employed. As the relationship between digital literacy skill and various variables such as gender, number of siblings, parents' education level, parents' profession was investigated; the relational survey model was employed. The sample of the study consisted of 742 fifth grade students who were students in 18 secondary schools located in the province of Erzincan in the spring term of 2017-2018 educational year. During determination of the sample, the intentional sampling technique was applied. As the data collection tool, the 'Personal Information Inventory' and 'Digital Literacy Scale' were used in the study.

During the process of finding answers to the research questions, the descriptive statistics were performed, the independent sampling t-test was applied for pairwise comparisons and one-way ANOVA to compare the averages related to the groups, which are more than two, and the TUKEY test was applied to determine the origin of the difference among variables in which significant difference was encountered.

\section{Results and Discussion}

The digital literacy skills scores of the students participated in the research were found to be high, in general.

As the digital literacy skills of the students according to their place of residence were taken into consideration, it was found that the digital literacy skill scores of the students living in the centre of the province had high score averages compared to the averages of students living in town connected to the city centre and in the centre of district. It was detected that the place of residence is effective in determining the digital literacy skills of the students.

It was found that the digital literacy scores of the students according to the gender were close to each other and the digital literacy scores did not demonstrate a significant difference depending on the gender.

As the digital literacy skill scores of the students were taken into consideration according to the number of siblings, it was observed that as the number of siblings increases, the digital literacy scores decrease. For this reason, it was concluded that the number of siblings was a significant variable determining the digital literacy skill scores. 
The variable of mother education status was found to affect the digital literacy skill levels of the students. It was concluded that as the education level of mother increases, the digital literacy skill increases, too.

The variable of father education status was found to be effective on the digital literacy skill levels of the students. It was observed that as the education level of father increases, the digital literacy skill level increases, too.

The profession of the mother was found to be effective on the digital literacy skill scores of the students. It was noticed that the students, whose mothers are civil servants, had the highest digital literacy skill score averages; on the other hand, the students, whose mothers are workers, had the lowest digital literacy skill score averages.

The profession of the father was found to be effective on the digital literacy skill scores of the students as well. It was noticed that the students, whose fathers are civil servants, had the highest self-control skill score averages; on the other hand, the students, whose fathers are workers, had the lowest scores.

The social studies lesson report marks were found to be a significant effect on the students' level of digital literacy skills. It was concluded that as the report marks of the students in social studies lesson increase, their digital literacy skill levels increase, too.

The status of students' having a computer or tablet at home was noticed to affect their digital literacy skill scores. It was concluded that the students who have computers or tablets at home have higher digital literacy skill levels compared to those who do not have computers or tablets.

It was determined that the digital literacy skill levels of the students, who have an internet connection at home, were significantly at higher level in terms of digital literacy skill level compared to the digital literacy skill levels of those who do not have an internet connection at home. The status of having a computer or tablet at home was noticed to have a significant effect on the digital literacy scores of the students.

The frequency of connecting to the Internet was also found to have a significant effect on the digital literacy skill levels of the students. In general, it was concluded that as the frequency of connecting to the Internet increased, the digital literacy skill levels of the students increased, too.

\section{Araştırmanın Etik Taahhüt Metni}

Yapılan bu çalışmada bilimsel, etik ve alıntı kurallarına uyulduğu; toplanan veriler üzerinde herhangi bir tahrifatın yapılmadığı, karşılaşılacak tüm etik ihlallerde "Cumhuriyet Uluslararası Eğitim Dergisi ve Editörünün" hiçbir sorumluluğunun olmadığ1, tüm sorumluluğun Sorumlu Yazara ait olduğu ve bu çalışmanın herhangi başka bir akademik yayın ortamına değerlendirme için gönderilmemiş olduğu sorumlu yazar tarafından taahhüt edilmiştir.

\section{Authors' Biodata/Yazar Bilgileri}

Şenol Mail PALA Erzincan Bilim ve Sanat Merkezi'nde sosyal bilgiler öğretmeni olarak görev yapmaktadır. Sosyal bilgiler eğitimi üzerine çalışmaları vardır. 
Şenol Mail Pala is a social sciences teacher at Erzincan Science and Art Center. He has studies on social science education.

Adem BAŞIBÜYÜK Erzincan Binali Yıldırım Üniversitesi, Fen-Edebiyat Fakültesi, Coğrafya Bölümü'nde Prof. Dr. olarak görev yapmaktadır. Beşeri coğrafya, tarihi coğrafya, coğrafya eğitimi ve sosyal bilgiler eğitimi üzerine çalışmaları vardır.

Adem Basıbuyuk works as Professor Dr. at Faculty of Arts and Sciences, Department of Geography at the Erzincan Binali Yıldırım University. He has studies on human geography, historical geography, geography education and social sciences education. 